\title{
Genealogías cubanas: la configuración crítica de una biblioteca
}

\author{
Sobre SiLva, Mara Guadalupe (2019). \\ El dragón en la biblioteca. Lezama Lima y la literatura cubana (1948-2002). \\ Buenos Aires: Katatay ediciones digitales, 289 pp.
}

Q Sonia Alejandra Bertón

Universidad Nacional de La Pampa

"Construir y alterar la cultura heredada", así podría decirse que es el modo en que Guadalupe Silva sintetiza y explica la metáfora del dragón en la biblioteca, figura que no solo da nombre a su libro sino que, más aún, tomada del propio José Lezama Lima, es lo que le permite a la autora dar el puntapié inicial a este análisis de largo aliento de la escritura y la literatura cubanas a lo largo de poco más de medio siglo. El dragón en la biblioteca es, según Silva, el modo en que Lezama, en el ensayo La cantidad hechizada elige para referirse a Confucio como quien pretende fundar y, a la vez, reinventar sus tradiciones, "construir y al mismo tiempo alterar la cultura heredada" (Silva, 2019: 13). Esta figura constituye una paradoja en tanto representa la voluntad confuciana de apresar en la biblioteca un saber inclasificable pero, además, se instaura como un modo principal de autofiguración del propio Lezama en la biblioteca cultural cubana.

El dragón en la biblioteca. Lezama Lima y la literatura cubana (1948-2002) es el resultado de un trabajo de investigación que se inició en la tesis doctoral sobre Lezama presentada en la Universidad de Buenos Aires, durante el año 2005. En este libro, Silva se propone analizar, precisamente, esa figura de lo inasimilable trazando un recorrido de lecturas que abarca textos desde los años cuarenta hasta finales del siglo $X X$, es decir, desde la última década de la Cuba republicana hasta los años postsoviéticos. Se trata de doce ensayos en los que aborda distintos autores y obras y se concentra en sus problemáticas particulares pero sin descuidar la construcción de ciertas conexiones y genealogías que permiten descubrir la configuración de una tradición literaria nacional en la que, sin lugar a dudas, José Lezama Lima ocupa un lugar ineludible. De tal modo, las dos partes en que se organiza el libro se concentran, por un lado, en el trabajo lezamiano y, por el otro, en textos y autores que han establecido vínculos y diálogos con Lezama.

En el primer capítulo "La disputa del presente. El debate Orígenes-Mañach", Silva analiza el intercambio que tuvo lugar, durante el año 1949, entre Jorge Mañach y
Lezama Lima y que tiene como puntapié la iniciativa de Lezama de enviarle una nota a Mañach, junto con un ejemplar de La fijeza, en la que le reprocha su distanciamiento del proyecto poético de Orígenes. En este debate, en el que otros actores se fueron incorporando a la escena a lo largo de poco más de un mes, lo que se puso en discrepancia fueron, principalmente, los principios de autonomía estética, defendidos por Lezama como revalorización de lo literario en tanto "vehículo de saber" (31) frente al principio de comunicatividad por el que bregaba Mañach.

Por su parte, en "Un poeta en la ciudad. Crónicas de 'La Habana'”, Silva analiza una serie de textos que Lezama publicó en Diario de la Marina en el mismo momento en que se desarrolla la polémica con Mañach en la revista Bohemia. Se trata de columnas reunidas bajo el título "La Habana", incorporadas en 1958 en Tratados en La Habana, en las que el cubano, según Silva, "sale a la calle a tomar posesión de la ciudad" (39), no como un cronista de lo real sino en tanto constructor de una poética de la "habanidad", una visión de lo cubano, que tiene como finalidad estrechar lazos con la tradición insular (40). No son, afirma Silva, crónicas ingenuas sino que tienen la intencionalidad de intervenir en la representación de la ciudad, en la construcción de una Habana familiar, metafórica, nostálgica de un pasado ideal frente a un presente en crisis.

Es esta imagen de la ciudad -familiar, simbólica, poética, en alguna medida utópica- precisamente la que le permite vincular a la autora las crónicas del Diario de la Marina con Paradiso (1966), novela que ocupará la centralidad de los tres capítulos siguientes y que, claramente, constituye uno de los temas de mayor interés en el libro. En "Paradiso (i). La novela y el origen", Silva analiza con agudeza la construcción híbrida del texto que perturba los límites categóricos del género fusionando poesía, narración y ensayo en el relato de la historia familiar de José Cemí en tanto metáfora del cuerpo patrio. Según la autora, Lezama funda su proyecto literario en el mandato materno de 
modo que Paradiso es, a un mismo tiempo, novela de formación y relato de origen sobre la propia novela, tanto como Cemí es, también a un mismo tiempo "un heredero y un fundador" (75).

Por otra parte, el erotismo y la homosexualidad son, sin lugar a dudas, temas de relevancia fundamental no solo en la obra lezamiana sino, más aún, en lo que respecta a su vida personal. Constituyen, por lo mismo, problemáticas centrales en el abordaje de Silva, quien le dedica el cuarto capítulo de su libro, "Paradiso (ii). Erotismo, literatura, homosexualidad". En este apartado, la autora analiza la novela y concluye que la homosexualidad, en Paradiso, no se limita a una cuestión constructiva de la trama o los personajes sino que, por el contrario, es un procedimiento que la impregna en todos sus niveles y por el cual es dado que solo los cuerpos masculinos son verdaderamente deseables. En este orden de cosas, según Silva, "Paradiso quebranta la doxa, desafía a los lectores y se expone a la censura. Sus clandestinos deseos sexuales no solamente no se contradicen con sus anhelos poéticos y metafísicos, sino que hacen sistema con ellos" (98).

En consonancia con los abordajes anteriores, Silva centra su último análisis sobre la novela lezamiana recurriendo nuevamente a la representación de Paradiso en vinculación con la metáfora de un cuerpo proliferante, en expansión, un "tejido anormal" que crece sin límites. Esta imagen -retomada en el capítulo siguiente para analizar el estilo barroco de Lezama-alude a un modo de escritura "que se multiplica y se desdobla", que es híbrida, que elude todo intento de pureza y que responde a un intento por sujetar lo inasible. En este mismo sentido, en "Lezama en los ochenta. Las imágenes posibles" Silva recupera esta figura de lo corporal y la proyecta en una lectura vinculada con la noción de barroco en la que propone una continuidad entre su imagen de escritor y su estilo, entre el cuerpo y la escritura. "Extravagante, auténtico, arraigado, universal, dispendioso y austero" (126) son algunos de los adjetivos con los que Silva califica a Lezama y por los que lo asume en sus contradicciones, en su barroquismo que, según ella, le nace del cuerpo y se continúa en su escritura y, por lo mismo, lo aleja de la percepción de escritor desarraigado y oscuro, propia de cierta crítica anterior.

"Lezama en su genealogía” es la perspectiva que estructura la segunda parte del libro y, más precisamente, el tópico de la escritura barroca, el derrotero que elige Silva para señalar los vínculos disímiles y contrapuestos con escritores como Alejo Carpentier, Severo Sarduy, Lorenzo García Vega y Reinaldo Arenas. Así, si Sarduy se denominó a sí mismo como "el heredero" no es porque el diálogo entre ellos haya sido unívoco sino, por el contrario, porque las ideas que el propio Sarduy desarrolló a partir de la obra lezamiana son, en la escritura del maestro, nociones que la permean. En sentido opuesto, el barroco de Carpentier se diferencia de ambos autores, lo que da lugar a dos tradiciones del barroco cubano y latinoamericano marcadamente diferentes.

En este orden de cosas, en "Contra el barroco: Lorenzo García Vega”, Silva analiza la postura que el escritor manifiesta en su libro Los años de Orígenes (1979) respecto del proyecto origenista, y que es, en todo caso, una de las primeras y más fuertes voces en su contra. El principal punto de crítica, en este sentido, gira, para Vega, en torno a un aspecto que considera fundamental en la poética origenista y que no es más que el culto lezamiano de la imagen. De tal modo, el barroco se configura, según la perspectiva de este autor, en consagración y mistificación de este "imperio de la imagen" en lugar de proponerse como su deconstrucción. La exigencia es, entonces, según la lectura que Silva realiza sobre el texto de Vega, no "contra el barroco en sí sino contra el uso político de las representaciones" (186).

En relación con El mundo alucinante (1966) de Reinado Arenas, Silva aborda la configuración de la disidencia en la novela tanto en su dimensión estética como en su aspecto vinculado con lo político. Según esta perspectiva, el personaje de Fray Servando funciona en tanto "construcción identificatoria" a partir de la cual el autor se posiciona frente al poder.

En los capítulos finales del libro, Silva se ocupa de analizar la literatura en torno a una etapa política e histórica reciente que incluye a la generación de los novísimos insertos en un contexto de marcada crisis económica e institucional por el cual fue la diáspora no solo una respuesta individual, social y política sino, aún más, un nuevo modo de hacer literatura. Así, en los capítulos 10 y 11 - "Ponte (i) por un Martí menor" y "Ponte (ii). Un arte de la ruina"- se centra en la figura de Antonio José Ponte con el fin de analizar su "poética de los restos"; es decir, Silva se interesa en un aspecto poco trabajado de la escritura del cubano que es, en términos de la autora, "el carácter corrosivo, deconstructivo y en última instancia demoledor de este programa literario que se plantea como una ciencia de la ruina" (214). En este sentido, el ensayo que le dedica a José Martí -figura máxima del heroísmo revolucionario- es uno de los textos en los que Ponte despliega esta poética de la ruina en tanto crítica política. De la misma manera, también su narrativa es una forma de interpelar el relato de lo nacional impugnando el 
esencialismo insularista y construyendo, en la metáfora de una Cuba “como un 'imperio' derramado", la idea de un territorio poco habitable.

Precisamente, es esta imagen de una Cuba signada por lo inhóspito, lo inhabitable y el exilio la que sustenta el proyecto de la revista Diáspora(s). Este es el último tema que Silva aborda en su libro y con el cual cierra el recorrido por la literatura cubana que iniciara en los años cuarenta con la lectura de los textos de José Lezama Lima. La revista se conformó en torno a un grupo de escritores relacionados por lazos de amistad, entre los que se contaban Rolando Sánchez Mejías y Carlos Aguilera como coordinadores, y Antonio José Ponte y Víctor Fowler, tal vez menos involucrados en el proyecto pero próximos al grupo. Como su nombre lo indica, la revista se constituyó como un espacio de voz para los exiliados cubanos aunque la palabra "diáspora(s)" adoptó diversos tintes. Por un lado, daba lugar no solo a los que se fueron de la isla forzados por causas políticas sino, además, a quienes lo hicieron por voluntad propia. Pero por otro lado, el juego entre el singular y la pluralidad que marca la presencia del significante " $s$ " entre paréntesis pone en evidencia que las posibles diásporas son, también, una cuestión de lenguaje y, por lo mismo, de literatura. Silva analiza en su último capítulo este proyecto gestado en los límites de una terraza habanera y resuelto en la impresión de una revista que se conformó como un espacio crítico de las políticas intelectuales del gobierno posrevolucionario pero, también, del proyecto origenista. Así, la autora cierra este recorrido a través del cual leyó y, en cierto modo, configuró una genealogía posible de la literatura cubana y, en algún sentido, se instaura ella misma en la metáfora del dragón en la biblioteca, en la operación doble de "Construir y alterar la cultura heredada". 